\author{
DOMINIKA CENDROWICZ \\ ORCID: 0000-0002-2358-7188 \\ Uniwersytet Wrocławski \\ Instytut Nauk Administracyjnych \\ Zakład Ustroju Administracji Publicznej
}

\title{
TEORIA RACJONALNEGO TWORZENIA PRAWA A USTAWODAWSTWO Z ZAKRESU POMOCY SPOŁECZNEJ. UWAGI NA TLE USTALANIA WŁAŚCIWOŚCI MIEJSCOWEJ GMINY W SPRAWACH PRZYZNAWANIA ŚWIADCZEŃ Z ZAKRESU POMOCY SPOŁECZNEJ NA RZECZ OSÓB BEZDOMNYCH
}

\begin{abstract}
Abstrakt: Przedmiot rozważań, prowadzonych w niniejszym artykule z punktu widzenia teorii racjonalnego ustawodawcy, stanowi regulacja art. 101 ustawy z dnia 12 marca 2004 roku o pomocy społecznej odnosząca się do sposobów ustalania właściwości miejscowej gminy w sprawach dotyczących przyznawania świadczeń z tej ustawy na rzecz osób bezdomnych. O aktualności przyjętego tematu publikacji świadczy to, że problematyka nim objęta stanowi przedmiot zainteresowania przedstawicieli literatury i praktyki, organu administracji publicznej, jakim jest Rzecznik Praw Obywatelskich $^{1}$, oraz jest przedmiotem licznych orzeczeń sądów administracyjnych. Regulacja ta zakłada pewnego rodzaju fikcję prawną mającą na celu zagwarantowanie osobom bezdomnym dostępu do świadczeń z zakresu pomocy społecznej ${ }^{2}$. Powoduje również pewne trudności na tle jej stosowania. Skutkują one między innymi powstawaniem sporów o właściwość między gminami w sprawach dotyczących udzielania świadczeń osobom bezdomnym. Obowiązująca regulacja przekłada się na sytuację prawną osób bezdomnych ubiegających się o przyznanie im świadczenia z zakresu pomocy społecznej, gdy faktycznie przebywają one na terenie innej gminy niż gmina ich ostatniego miejsca zameldowania. W publikacji zastosowano metody teoretyczno-prawną oraz empiryczno-prawną.
\end{abstract}

Słowa kluczowe: racjonalność, pomoc społeczna, osoba bezdomna, gmina, właściwość miejscowa, spory o właściwość

\footnotetext{
1 Dalej: RPO.

2 Postanowienie NSA z dnia 17 listopada 2017 roku, I OW 241/17, CBOSA.
} 


\section{WPROWADZENIE}

W procesie tworzenia norm prawnych uczestniczą różni ludzie. Wśród nich są politycy, eksperci oraz legislatorzy. To oni wywierają rzeczywisty wpływ na treść i jakość tworzonego prawa, jego kształt formalny oraz aksjologię. W prawoznawstwie noszą oni nazwę prawodawcy faktycznego. Od tego rodzaju prawodawcy odróżnia nauka prawa prawodawcę formalnego, czyli podmiot wyposażony w kompetencje prawodawcze, który dokonuje konwencjonalnego aktu stanowienia prawa ${ }^{3}$. To właśnie prawodawca formalny pełni w prawoznawstwie funkcję pewnego wzoru, do którego prawodawca faktyczny powinien dążyć przy tworzeniu prawa ${ }^{4}$. Stanowione przez prawodawcę faktycznego prawo powinno odwzorowywać określone zasady i wartości, a także spełniać postulaty dobrego jakościowo prawa. Dobre jakościowo prawo, a przynajmniej prawo przyzwoite/ poprawne to takie, które urzeczywistnia normy, wartości i zasady wywodzone z Konstytucji RP z dnia 2 kwietnia 1997 roku$^{5}$, w tym zasadę demokratycznego państwa prawnego wyrażoną w jej art. $2^{6}$. Do pozostałych zasad, które wyraża dobre jakościowo prawo, zalicza się zasadę ochrony zaufania do państwa i tworzonego przez nie prawa, zasadę lojalności państwa względem jego obywateli, pewności prawa i bezpieczeństwa prawnego, zasadę niedziałania prawa wstecz, zasadę vacatio legis, zasadę ochrony praw słusznie nabytych, odpowiedniej jakości prawa, jego proporcjonalności oraz — co należy podkreślić — jego racjonalności. Przedmiotowe zasady ugruntowane zostały w orzecznictwie Trybunału Konstytucyjnego ${ }^{7}$. Wciąż jednak zdarzają się sytuacje, w których tworzone przez prawodawcę faktycznego prawo nie odpowiada w pełni tym zasadom.

Postulatowi tworzenia dobrego jakościowo/przyzwoitego prawa sprzyja założenie o racjonalności prawodawcy ${ }^{8}$. Zakłada ono istnienie prawodawcy tworzącego przepisy w sposób sensowny, racjonalny i celowy. Prawodawca racjonalny zna system prawny. Nadaje poszczególnym słowom i zwrotom takie samo znaczenie. Jednocześnie nie zamieszcza on zbędnych sformułowań w tekstach tworzonych przez siebie aktów prawnych ${ }^{9}$. Teoria racjonalnego prawodawcy zdaje się być wy-

3 S. Wronkowska, Podstawowe pojęcia prawa i prawoznawstwa, Poznań 2003, s. 29.

${ }^{4}$ S. Wronkowska, Prawodawca formalny jako wzór dla prawodawcy faktycznego, [w:] Szkice z teorii prawa i szczegółowych nauk prawnych, red. S. Wronkowska, M. Zieliński, Poznań 1990, s. 121.

5 Konstytucja RP z dnia 2 kwietnia 1997 roku (Dz.U. Nr 78, poz. 483 z późn. zm.).

6 Z. Duniewska et al., Ku dobremu prawu. Z problematyki pojęcia i wymogów dobrego prawa, [w:] Racjonalny ustawodawca. Racjonalna administracja. Pamięci prof. Eugeniusza Smoktunowi$c z a$, red. D.R. Kijowski, A. Miruć, A. Budnik, Białystok 2016, s. 22.

7 Ibidem, s. 22-23.

8 Koncepcję tę upowszechnił w literaturze krajowej L. Nowak. Zob. idem, Interpretacja prawnicza. Studium z metodologii prawoznawstwa, Warszawa 1973. Por. J. Czaja, O nieracjonalności pojęcia , racjonalnego ustawodawcy”, [w:] Studia z filozofii prawa, red. J. Stelmach, Kraków 2001, s. $175-185$.

9 Wyrok WSA w Warszawie z dnia 9 grudnia 2010 roku, III SA/Wa 2114/10, CBOSA. 
nikiem założenia o jednym autorze tekstu prawnego, a więc o istnieniu prawodawcy idealnego ${ }^{10}$. Jej istotą jest przeświadczenie, że możliwe jest mądre, rozsądne i sprawiedliwe stanowienie prawa ${ }^{11}$. Racjonalny prawodawca respektuje model racjonalnego tworzenia prawa ${ }^{12}$. Do podmiotowych wyznaczników jego postępowania należą niesprzeczność jego wiedzy oraz fakt, że stanowi ona system obejmujący logicznie swoje konsekwencje, asymetryczność preferencji prawodawcy oraz ich przechodniośćc 13 .

Racjonalność to jeden z postulatów odnoszonych do administracji publicz$n j^{14}$. Tworzone przez racjonalnego prawodawcę prawo sprzyja funkcjonowaniu racjonalnej administracji i odnoszone jest do jej działań ${ }^{15}$. Prawo administracyjne, „ustalając podstawy tych działań, powinno je formułować tak, aby powodowały racjonalne zachowanie się organów administracyjnych" ${ }^{16}$. W tym miejscu należy zwrócić uwagę na tę cechę prawa administracyjnego, zgodnie z którą reguluje ono nieomal wszystkie przestrzenie życia społecznego ${ }^{17}$. Dla jednostki ważne znaczenie mają normy materialnego prawa administracyjnego. One to bowiem stanowią źródło jej uprawnień oraz interesów prawnych ${ }^{18}$. Prawo materialne nie mogłoby jednak istnieć bez prawa procesowego, ponieważ jest ono narzędziem, za pośrednictwem którego są wprowadzane w życie normy prawa materialnego ${ }^{19}$. Racjonalnie należy także projektować ustrój administracji publicznej. Z punktu widzenia jednostki obywatela teoria racjonalnego prawodawcy odnoszona do administracji publicznej oraz do prawa administracyjnego powinna stanowić ważny element idei ustrojowej, a nie jedynie fikcję prawną ${ }^{20}$. Administracja publiczna oraz prawo administracyjne wpływają bowiem na żywotne sprawy dnia codziennego każdego człowieka ${ }^{21}$.

10 M. Matczak, Summa iniuria. O błędzie formalizmu w stosowaniu prawa, Warszawa 2007, s. 187.

11 T. Chauvin, T. Stawecki, P. Winczorek, Wstęp do prawoznawstwa, Warszawa 2017, s. 208.

12 J. Wróblewski, Teoria racjonalnego tworzenia prawa, Wrocław 1985, s. 134-135.

13 L. Nowak, op. cit., s. 39.

14 J. Zimmermann, Aksjomaty prawa administracyjnego, Warszawa 2012, s. 88.

15 I. Lipowicz, Kilka uwag w kwestii racjonalności w prawie administracyjnym, [w:] Racjonalny ustawodawca. Racjonalna administracja. Pamięci Profesora Eugeniusza Smoktunowicza, red. D.J. Kijowski, A. Miruć, A. Budnik, Białystok 2016, s. 64 n.

16 J. Zimmermann, op. cit., s. 88.

17 D. Cendrowicz, Przestrzeń pewności prawnej jednostki w materialnym i procesowym prawie administracyjnym, [w:] Przestrzeń w prawie administracyjnym, red. J. Zimmermann, Warszawa 2013, s. 34.

18 Wyrok NSA z dnia 29 stycznia 1992 roku, I SA 1355/91, „Wspólnota” 1992, nr 18, poz. 17.

19 B. Adamiak, Funkcje prawa o postępowaniu administracyjnym i prawa o postepowaniu sqdowoadministracyjnym, [w:] Postepowanie administracyjne i sadowoadministracyjne, red. B. Adamiak, J. Borkowski, Warszawa 2009, s. 18.

20 I. Lipowicz, op. cit., s. 63.

21 T. Kuta, Sytuacja człowieka we wspótczesnej administracji, „Prawo” 2, Wrocław 1972, s. 107. 


\section{O POTRZEBIE RACJONALNEGO TWORZENIA PRAWA W POMOCY SPOŁECZNEJ}

Potrzeba racjonalnego tworzenia prawa odnoszona jest do całości działań administracji publicznej oraz regulujących ich norm prawa administracyjnego. W szczególności odnoszona jest do tych obszarów działalności administracji publicznej, a w konsekwencji do tych sfer regulacji prawa administracyjnego, które skierowane są do osób znajdujących się w pewnych trudnych, częstokroć krytycznych sytuacjach życiowych, których nie są w stanie przezwyciężyć samodzielnie i przy wykorzystaniu własnych uprawnień, zasobów oraz możliwości. W konsekwencji osoby te zmuszone są zwrócić się o pomoc do administracji publicznej, ,aby móc w miarę godnie funkcjonować, a nierzadko także, aby przeżyć" 22 . W kontekst ten wpisuje się bezspornie aktywność administracji publicznej z zakresu pomocy społecznej, która regulowana jest w obecnym stanie prawnym przepisami ustawy z dnia 12 marca 2004 roku o pomocy społecznej ${ }^{23}$.

Pomoc społeczna uznawana jest dzisiaj za część tak zwanej administracji świadczącej. Podstawowym celem administracji świadczącej w pomocy społecznej jest zaspokajanie potrzeb bytowych człowieka. Administracja pomocy społecznej zaspokaja potrzeby człowieka poprzez świadczenia w postaci zasiłków pieniężnych oraz rzeczowych, a także poprzez usługi ${ }^{24}$. Katalog licznych świadczeń pomocy społecznej określa art. 36 u.p.s. Otwarty katalog przyczyn, które powodują, że jednostka lub rodzina może ubiegać się o tego rodzaju świadczenia, wymienia art. 7 u.p.s. Zgodnie z przedmiotowym artykułem beneficjentem świadczeń z u.p.s. można stać się w szczególności z powodu ubóstwa, bezrobocia, bezdomności, niepełnosprawności, długotrwałej lub ciężkiej choroby, przemocy w rodzinie, a także z uwagi na bezradność w sprawach opiekuńczo-wychowawczych i prowadzenia gospodarstwa domowego, zwłaszcza w rodzinach niepełnych lub wielodzietnych.

Ważne i niechlubne miejsce wśród określonych art. 7 u.p.s. przyczyn udzielania świadczeń zajmuje bezdomność. Jest to kategoria wykluczenia społecznego, która spycha ludzi nią dotkniętych na margines społeczeństwa i powoduje, że staje się ona dla większości z nich sytuacją bez wyjścia ${ }^{25}$. Osoby nią dotknięte narażone są nie tylko na wykluczenie społeczne, ale niejednokrotnie stają się też ofiarami przestępstw, takich jak pobicia czy kradzieże ${ }^{26}$. Znajdują się ponadto

22 D. Cendrowicz, Sytuacja administracyjnoprawna adresata świadczeń z zakresu pomocy społecznej, Warszawa 2017, s. 15.

${ }^{23}$ Ustawa z dnia 12 marca 2004 roku o pomocy społecznej (tekst jedn. Dz.U. z 2019 r. poz. 1507 z późn. zm.; dalej: u.p.s.

${ }^{24}$ I. Sierpowska, Pomoc społeczna jako administracja świadcząca, Warszawa 2012, s. 171, 197.

${ }^{25}$ Wyrok WSA w Białymstoku z dnia 26 sierpnia 2014 roku, II SA/Bk 451/14, CBOSA.

${ }^{26}$ E.M. Truskolaska, Kryminologiczne aspekty bezdomności, rozprawa doktorska, Białystok 2018, https://repozytorium.uwb.edu.pl/jspui/bitstream/11320/7113/1/EM_Truskolaska_Kryminologiczne_aspekty_bezdomnosci.pdf, s. 104 (dostęp: 22.12.2019). 
w stanie, który narusza podstawową godność człowieka. Potrzeba racjonalnego tworzenia prawa w pomocy społecznej, mającej za cel udzielanie pomocy bezdomnym, nie powinna budzić zatem wątpliwości. Praworządność, ochrona praw człowieka oraz racjonalne stanowienie i stosowanie prawa są tutaj niezbędne ${ }^{27}$.

\section{OSOBA BEZDOMNA JAKO ADRESAT ŚWIADCZEŃ Z ZAKRESU POMOCY SPOŁECZNEJ}

Ustawodawca, przyjmując bezdomność za podstawę do udzielania świadczeń $z$ u.p.s., wprowadził prawną definicję osoby bezdomnej na potrzeby ustalania uprawnień do tych świadczeń z tytułu bezdomności. Zawarta jest ona $\mathrm{w}$ art. 6 pkt 8 u.p.s. Zgodnie z nią osobą bezdomną jest osoba niezamieszkująca w lokalu mieszkalnym (w rozumieniu przepisów o ochronie praw lokatorów i mieszkaniowym zasobie gminy) i niezameldowana na pobyt stały (w rozumieniu przepisów o ewidencji ludności), a także osoba niezamieszkująca w lokalu mieszkalnym i zameldowana na pobyt stały w lokalu, w którym nie ma możliwości zamieszkania. Zawarta w art. 6 pkt 8 u.p.s. definicja przewiduje dwa odrębne stany faktyczne pozwalające na uznanie danej osoby za bezdomną. Pierwszy odnosi się do sytuacji, w której dana osoba nie mieszka w lokalu mieszkalnym i jednocześnie nie ma stałego zameldowania. Drugi odnosi się natomiast do osoby niezamieszkującej w lokalu mieszkalnym, ale mającej stałe zameldowanie w tym lokalu, jednak bez możliwości zamieszkania w nim. Podkreślić należy, iż w przypadku każdego z tych stanów przesłanki określone u.p.s. muszą występować łącznie ${ }^{28}$.

Warto zaznaczyć, że u.p.s. na potrzeby definicji osoby bezdomnej nie wprowadza definicji lokalu mieszkalnego. Pojęcie to należy więc odczytywać w związku $\mathrm{z}$ treścią art. 2 ust. 1 pkt 4 ustawy z dnia 21 czerwca 2001 roku o ochronie praw lokatorów, mieszkaniowym zasobie gminy i o zmianie Kodeksu cywilnego ${ }^{29}$. Lokal mieszkalny to lokal służący do zaspokajania potrzeb mieszkaniowych. Nie są nim pomieszczenia przeznaczone do krótkotrwałego pobytu osób, w szczególności znajdujące się w budynkach internatów, burs, pensjonatów, hoteli, domów wypoczynkowych lub w innych budynkach służących do celów turystycznych lub wypoczynkowych. W analizowanym przepisie mamy do czynienia z przykładowym charakterem tego wyliczenia. Pomieszczenia przeznaczone do krótkotrwałego pobytu osób, nawet te, które w u.o.p.l. nie zostały wprost wymienione, w jej rozumieniu nie stanowią lokali mieszkalnych. Do lokali mieszkalnych nie zalicza się więc schronisk dla bezdomnych, w którym schronienie stanowi jedno ze świadczeń normowanych u.p.s. ${ }^{30}$

27 I. Lipowicz, op. cit., s. 72.

28 Postanowienie NSA z dnia 4 listopada 2015 roku, I OW 156/15, CBOSA.

29 Ustawa z dnia 21 czerwca 2001 roku o ochronie praw lokatorów, mieszkaniowym zasobie gminy i o zmianie Kodeksu cywilnego (tekst jedn. Dz.U. z 2019 r. poz. 1182 z późn. zm.).

30 Postanowienie NSA z dnia 4 listopada 2015 roku, I OW 156/15, CBOSA. 
Osoba bezdomna może w praktyce ubiegać się o wszystkie świadczenia normowane u.p.s. Do świadczeń adresowanych w szczególności do osób bezdomnych należą: zasiłek celowy na pokrycie części lub całości wydatków na świadczenia zdrowotne (art. 39 ust. 3 u.p.s.), tymczasowe schronienie w noclegowni, schronisku lub ogrzewalni (art. 48a u.p.s.), pomoc w formie ubrań i żywnościowa (art. 48 u.p.s.). Osoby bezdomne mogą zostać także objęte indywidualnym programem wychodzenia z bezdomności (art. 49 u.p.s.). Świadczenie pracy socjalnej na rzecz bezdomnych jest również jednym ze świadczeń pomocy społecznej. Podkreślić należy, że osoby bezdomne mogą być kierowane do domów pomocy społecznej. Bezdomność może być także przyczyną udzielania pomocy w formie świadczenia, jakim jest interwencja kryzysowa (art. 47 u.p.s.).

\section{PRZYZNAWANIE ŚWIADCZEŃ Z ZAKRESU POMOCY SPOŁECZNEJ NA RZECZ OSÓB BEZDOMNYCH NA PODSTAWIE DECYZJI ADMINISTRACYJNEJ}

W pomocy społecznej regułą jest przyznawanie świadczeń w drodze decyzji administracyjnej (art. 106 ust. 1 u.p.s.). Równocześnie jednak u.p.s. wprowadza w art. 106 ust. 2 wyjątek od tej zasady. Zgodnie z przedmiotowym artykułem nie wymaga wydania decyzji administracyjnej udzielenie świadczeń w postaci interwencji kryzysowej, pracy socjalnej, poradnictwa, uczestnictwa w zajęciach klubu samopomocy, klubu samopomocy dla osób z zaburzeniami psychicznymi, schronienia $\mathrm{w}$ formie ogrzewalni i noclegowni, sprawienia pogrzebu, a także przyznania biletu kredytowanego. W świetle powyższego nie jest konieczne, aby przed udzieleniem bezdomnemu schronienia w ogrzewalni lub noclegowni przeprowadzać stosowne postępowanie administracyjne. Konieczność taka jednak zachodzi, gdy osoba bezdomna stara się o przyznanie schronienia w schronisku dla bezdomnych. Ta forma pomocy przyznawana jest bowiem na podstawie decyzji administracyjnej ${ }^{31}$.

Postępowanie administracyjne $\mathrm{w}$ sprawie przyznania świadczenia $\mathrm{z}$ pomocy społecznej toczy się według przepisów u.p.s. W sprawach nieuregulowanych w u.p.s. stosuje się odpowiednio przepisy ustawy z dnia 14 czerwca 1960 roku - Kodeks postępowania administracyjnego ${ }^{32}$, jeżeli u.p.s. nie stanowi inaczej ${ }^{33}$. Zgodnie z art. 19 k.p.a. w postępowaniu administracyjnym dotyczącym ustalenia uprawnienia do świadczenia z u.p.s. organy administracji publicznej są z urzędu obowiązane przestrzegać swojej właściwości. Pod pojęciem właściwości organu administracji publicznej rozumie się zdolność prawną danego organu do rozpoznania

31 Jego ważnym elementem w pomocy społecznej jest wywiad środowiskowy.

32 Ustawa z dnia 14 czerwca 1960 roku - Kodeks postępowania administracyjnego (tekst jedn. z 2018 r. poz. 2096 z późn. zm.); dalej: k.p.a.

33 Stanowi o tym art. 14 u.p.s. 
i rozstrzygnięcia określonego rodzaju sprawy w postępowaniu administracyjnym. Wyróżnia się dwa rodzaje właściwości - ustawową oraz delegacyjną. Właściwość ustawowa wynika wprost z przepisu ustawy. W jej zakresie znajdują się: właściwość rzeczowa, miejscowa oraz instancyjna. Właściwość rzeczową organu ustala się według przepisów o zakresie jego działania. Właściwość miejscowa to zdolność prawna organu administracji publicznej do rozstrzygania danej kategorii spraw na obszarze określonej jednostki podziału terytorialnego kraju. Właściwość instancyjna oznacza prawną zdolność organu do weryfikacji decyzji w drodze decyzji administracyjnej. Właściwość delegacyjna wynika z przekazania danej sprawy lub czynności procesowej w sprawie jednemu organowi administracji publicznej przez drugi ${ }^{34}$.

W pomocy społecznej właściwość rzeczową do przyznawania świadczeń normowanych tą ustawą mają gminy, a następnie powiaty. Przyjęte rozwiązanie wynika z art. 17-20 u.p.s. określających, które zadania pomocy społecznej realizują gminy, a które powiaty. W kontekście pomocy udzielanej bezdomnym należy wskazać, że gminy w świetle art. 17 ust. 1 pkt 3, 7 i 10 u.p.s. w ramach zadań własnych o charakterze obowiązkowym odpowiedzialne są za udzielanie im schronienia, przyznawanie i wypłacanie zasiłków celowych na pokrycie wydatków na świadczenia zdrowotne oraz do świadczenia pracy socjalnej. Do zadań własnych gminy o charakterze obligatoryjnym należy także sprawienie pogrzebu na rzecz zmarłego bezdomnego (art. 17 ust 1 pkt 15 u.p.s.). Zgodnie z art. 39 ust. 1 ustawy z dnia 8 marca 1990 roku o samorządzie gminnym ${ }^{35}$ organem upoważnionym w gminie do wydawania decyzji administracyjnych w pierwszej instancji jest wójt (burmistrz/prezydent miasta). Jak stanowi jednak art. 110 ust. 7 u.p.s., ma on obowiązek udzielenia upoważnienia do wydawania decyzji w sprawach z pomocy społecznej należących do właściwości gminy kierownikowi ośrodka pomocy społecznej ${ }^{36}$. Gminy są właściwe do rozstrzygania spraw z zakresu pomocy społecznej w pierwszej instancji. W drugiej instancji sprawy te są rozstrzygane przez samorządowe kolegia odwoławcze.

\section{ZASADY USTALANIA WŁAŚCIWOŚCI MIEJSCOWEJ GMINY W POSTĘPOWANIU ADMINISTRACYJNYM DOTYCZACACCYM PRZYZNANIA ŚWIADCZENIA Z ZAKRESU POMOCY SPOŁECZNEJ NA RZECZ OSOBY BEZDOMNEJ}

Do sposobów ustalania właściwości miejscowej organów gminy w sprawach dotyczących ustalania uprawnień do świadczeń z pomocy społecznej odnosi się art. 101 u.p.s. Przepis ten w ust. 1 stanowi, iż „właściwość miejscową gminy ustala

34 B. Adamiak, [w:] Kodeks postępowania administracyjnego. Komentarz, red. B. Adamiak, J. Borkowski, Warszawa 2014, s. 112.

35 Ustawa z dnia 8 marca 1990 roku o samorządzie gminnym (tekst jedn. Dz.U. z 2019 r. poz. 506 z późn. zm.).

36 Wyrok WSA w Olsztynie z dnia 21 maja 2013 roku, II SA/O1 329/13, CBOSA. 
się według miejsca zamieszkania osoby ubiegającej się o świadczenie”. W ustępie drugim stanowi, że „w przypadku osoby bezdomnej właściwą miejscowo jest gmina ostatniego miejsca zameldowania tej osoby na pobyt stały". Jeszcze inną zasadę wprowadza ustęp 3. tego artykułu. Jego treść stanowi, że w przypadkach szczególnie uzasadnionych sytuacją osobistą osoby ubiegającej się o świadczenie, w sprawach niecierpiących zwłoki oraz w sprawach cudzoziemców, którym udzielono zgody na pobyt ze względów humanitarnych lub zgody na pobyt tolerowany, i cudzoziemców, o których mowa w art. 5a u.p.s., właściwa miejscowo jest gmina miejsca pobytu osoby ubiegającej się o świadczenie. Zgodnie natomiast $\mathrm{z}$ art. 101 ust. 6 u.p.s. dla mieszkańca domu pomocy społecznej właściwa jest gmina, która skierowała go do tego domu.

W odniesieniu do art. 101 ust. 2 u.p.s. należy podkreślić, że wprowadza on odrębne zasady ustalania właściwości miejscowej gminy na potrzeby ustalania uprawnień do świadczeń z zakresu pomocy społecznej na rzecz osób bezdomnych. Dla osoby bezdomnej właściwą miejscowo jest gmina ostatniego jej miejsca zameldowania na pobyt stały, a nie gmina miejsca jej zamieszkania. Przyjęte rozwiązanie wynika stąd, że w odniesieniu do osób bezdomnych — z przyczyn obiektywnych - nie może być mowy o posiadaniu przez nie miejsca zamieszkania ${ }^{37}$. Wprowadzenie więc $\mathrm{w}$ art. 101 ust. 2 u.p.s. odrębnej zasady ustalania właściwości miejscowej gminy dla osób bezdomnych w postępowaniu administracyjnym wynika stąd, iż nie jest w praktyce możliwe ustalenie ich zamiaru stałego pobytu. Ustalenie zamiaru stałego pobytu jest zaś niezbędne przy określaniu miejsca zamieszkania w świetle art. 25 ustawy z dnia 23 kwietnia 1964 roku - Kodeks cywilny ${ }^{38}$. Miejsca zamieszkania nie należy natomiast mylić z miejscem zameldowania na pobyt stały. Miejsce zamieszkania oznacza miejscowość, w której dana osoba przebywa z zamiarem stałego pobytu. Obowiązek meldunkowy wynika natomiast z ustawy z dnia 24 września 2010 roku o ewidencji ludności ${ }^{39}$. Polega na zameldowaniu się w miejscu pobytu stałego lub czasowego.

W postanowieniu z dnia 22 lipca 2011 roku, OW 68/11, NSA wskazał, iż przyjęty w art. 101 ust. 2 u.p.s. sposób wyznaczania właściwości miejscowej gminy w sprawach dotyczących osób bezdomnych ma na celu zagwarantowanie tym osobom łatwego dostępu do świadczeń pomocy społecznejej ${ }^{40}$ Zdaniem tego sądu, wyrażonym w wyroku z dnia 4 grudnia 2007 roku, I OW 49/07, dla ustalenia gminy właściwej miejscowo do udzielenia pomocy społecznej osobie bezdomnej zameldowanej na pobyt stały nie mają znaczenia okoliczności towarzyszące wykonaniu obowiązku meldunkowego, w tym przede wszystkim, czy realizacja tego obowiąz-

37 Postanowienie NSA z dnia 4 listopada 2011 roku, I OW 156/15, CBOSA.

38 Ustawa z dnia 23 kwietnia 1964 roku - Kodeks cywilny (tekst jedn. Dz.U. z 2019 r. poz. $1145 \mathrm{z}$ późn. zm.).

39 Ustawa z dnia 24 września 2019 roku ewidencji ludności (tekst jedn. Dz.U. z 2019 r. poz. 1397 z późn. zm.); dalej: u.o.e.l.

40 Postanowienie NSA z dnia 22 lipca 2011 roku, I OW 68/11, CBOSA. 
ku nastąpiła zgodnie z przepisami u.o.e.1. ${ }^{41}$ Ustalając właściwość miejscową gminy, nie bada się zamiaru osoby bezdomnej co do jej stałego pobytu, ale ustala się jej status ${ }^{42}$. Nawet jeśli dana osoba deklaruje zamiar stałego pobytu w określonej miejscowości, to dla ustalenia właściwości miejscowej organu pomocy społecznej nie ma to znaczenia. Gminą właściwą dla takiej osoby jest gmina ostatniego jej miejsca zameldowania na pobyt stały.

Należy jednak zwrócić uwagę na inną ważną kwestię związaną z ustalaniem właściwości miejscowej gminy w sprawach dotyczących bezdomnych na podstawie art. 101 ust. 2 u.p.s. Przepis ten, jak wielokrotnie podkreślano, stanowi, że właściwą w sprawie ustalenia uprawnienia do świadczenia na rzecz osoby bezdomnej jest gmina jej ostatniego miejsca zameldowania. W praktyce występują sytuacje, w których bezdomni starają się o pobyt w schronisku na terenie gminy, w której faktycznie przebywają, a nie w gminie ich ostatniego zameldowania na pobyt stały. Dzieje się tak, dlatego że więź łącząca takie osoby z gminą ich ostatniego miejsca zameldowania nie istnieje, a one same dokonały wyboru co do miejsca swojego pobytu ${ }^{43}$. Właściwą miejscowo w ich sprawie pozostaje jednak gmina ostatniego miejsca zameldowania i to ona ma obowiązek ponoszenia wydatków za pobyt osoby bezdomnej w schronisku. Gmina ostatniego miejsca zameldowania może jednak uznać, iż opłata za pobyt w schronisku w gminie, w której chciałby przebywać bezdomny, jest nieproporcjonalnie wysoka do opłaty za pobyt w schronisku na terenie gminy właściwej miejscowo lub innej gminy, jeżeli gmina ostatniego miejsca zameldowania nie prowadzi na swoim terenie schroniska dla bezdomnych. Dla bezdomnych, którzy w wielu przypadkach nie czują się już emocjonalnie związani z gminą ostatniego miejsca swojego zameldowania na pobyt stały i które swoim centrum życiowym uczyniły miejscowości znajdujące się na terenie innych gmin, taka decyzja organu właściwego w sprawie jest niejednokrotnie dramatyczna i może powodować nieefektywność świadczonej pomocy, a w konsekwencji zaprzestanie wychodzenia z bezdomności.

Można spotkać się z opinią, zgodnie z którą, w przypadku osób, które często zmieniają miejsce swojego pobytu, ustalanie właściwości miejscowej zgodnie $\mathrm{z}$ art. 101 ust. 2 u.p.s. jest zasadne, ale może powodować nieefektywność pomocy świadczonej bezdomnym, którzy nie chcą uczynić swoim centrum życiowym gmin ostatniego miejsca zameldowania ${ }^{44}$. Warto więc zwrócić uwagę na postulaty, jakie

41 Postanowienie NSA z dnia 4 grudnia 2007 roku, I OW 49/07, CBOSA.

42 Postanowienie NSA z dnia 4 kwietnia 2007 roku, I OW 109/06, CBOSA.

43 Wystąpienie RPO do Ministerstwa Rodziny z dnia 11 października 2018 roku w sprawie problemów osób w kryzysie bezdomności, III.7065.193.2018.JJ, https://www.rpo.gov.pl/sites/default/files/Wystapienie_RPO_do_Ministerstwa_Rodziny_ws_problemow_osob_w_kryzysie_bezdomnosci.pdf (dostęp: 23.12.2019).

44 S. Jóźwik, I. Klimowicz, O postępowaniu z bezdomnymi. Cz. II, „Doradca w pomocy społecznej" 49 (listopad 2017), https://doradcawpomocyspolecznej.pl/artykul/o-postepowaniu-z-bezdomnymi-cz-ii (dostęp: 23.12.2019). 
w zakresie obowiązującej regulacji prawnej są zgłaszane przez RPO. Zawierają one przykładowo propozycję stworzenia tak zwanego „koszyka świadczeń”, którego realizacji bezdomni mogliby domagać się na terenie całego kraju, a więc bez względu na miejsce swojego pobytu. W ocenie RPO takie rozwiązanie sprzyjałoby między innymi większemu respektowaniu woli osoby bezdomnej w zakresie miejsca jej przebywania. Przedmiotowy postulat odnosi się do świadczeń niepieniężnych z pomocy społecznej — w szczególności do świadczenia w formie schronienia ${ }^{45}$.

W nawiązaniu do powyższego należy wskazać na treść art. 101 ust. 3 u.p.s. wprowadzającego odstępstwo od przyjętej w art. 101 ust. 2 u.p.s. reguły ustalania właściwości miejscowej gminy. Zawarte w art. 101 ust. 3 u.p.s. rozwiązanie przewiduje przeniesienie właściwości miejscowej w sprawach dotyczących bezdomnych z gminy, w której dana osoba miała ostatnie zameldowanie na pobyt stały, na gminę miejsca pobytu takiej osoby. Sytuacja taka — w świetle analizowanego przepisu — może mieć miejsce tylko w przypadkach szczególnie uzasadnionych. W odniesieniu do bezdomnych za szczególnie uzasadniony przypadek uznać można na przykład sytuację materialną oraz warunki, w jakich zamieszkuje bezdomny, przy uwzględnieniu, iż lokal, w którym on zamieszkuje, nie stanowi lokalu mieszkalnego w rozumieniu art. 2 ust. 1 pkt 4 u.o.p.l. W miejscu pobytu mogą być udzielone świadczenia wymienione $\mathrm{w}$ art. 37-42 u.p.s. oraz $\mathrm{w}$ art. 47-50 u.p.s. Wśród świadczeń tych znajdują się istotne z punktu widzenia osób bezdomnych, jak na przykład interwencja kryzysowa, schronienie, posiłek, niezbędne ubranie, objęcie indywidualnym programem wychodzenia $\mathrm{z}$ bezdomności ${ }^{46}$. Treść art. 103 ust. 3 u.p.s. zakłada więc, że w określonych sytuacjach faktycznych niezbędna i bardziej efektywna jest pomoc świadczona przez gminę, w której aktualnie osoba bezdomna przebywa, aniżeli przez gminę jej ostatniego zameldowania ${ }^{47}$. W sytuacjach nagłych, w których zagrożone byłoby na przykład zdrowie lub życie bezdomnego, nie powinno się zatem odsyłać go do gminy jego ostatniego miejsca zameldowania.

\section{SPORY O WŁAŚCIWOŚĆ MIEJSCOWĄ MIĘDZY GMINAMI W SPRAWACH DOTYCZĄCYCH PRZYZNAWANIA ŚWIADCZEŃ Z ZAKRESU POMOCY SPOŁECZNEJ NA RZECZ OSÓB BEZDOMNYCH}

Przyznawanie przez gminy świadczeń osobom bezdomnym nierzadko skutkuje sporami o właściwość miejscową. Spór o właściwość to sytuacja, w której

45 Pomyst ekspertów RPO: pomoc dla osoby bezdomnej - w catym kraju, a nie tam, gdzie była ostatnio zameldowana, https://www.rpo.gov.pl/pl/content/rpo-trzeba-zmienic-zasady-pomagania-osobom-w-kryzysie-bezdomnosci (dostęp: 21.12.2019).

46 S. Nitecki, Komentarz do ustawy o pomocy spolecznej wraz z przepisami wykonawczymi, Wrocław 2013, s. 704.

47 Postanowienie NSA z dnia 18 maja 2015 roku, I OW 94/17, CBOSA. 
zachodzi wątpliwość, który z co najmniej dwóch organów pozostających w sporze jest właściwy do rozstrzygnięcia danej sprawy administracyjnej. Spór o właściwość może przybrać postać sporu pozytywnego lub negatywnego. Spór pozytywny to taki, w którym co najmniej dwa organy administracji publicznej uznają, że są właściwe w danej sprawie. Spór negatywny ma miejsce, gdy dwa (lub więcej) organy pozostające w sporze uznają się za niewłaściwe do rozstrzygnięcia danej sprawy ${ }^{48}$. Spory o właściwość w sprawach udzielania świadczeń bezdomnym związane są głównie z tym, która z gmin pozostających w sporze jest właściwa do rozpoznania wniosku o przyznanie świadczenia, a w konsekwencji do poniesienia wydatków związanych z udzieloną pomocą. Spory o właściwość w sprawach osób bezdomnych są więc niejednokrotnie konsekwencją obowiązku zwrotu wydatków za udzielone bezdomnemu świadczenie. Jak stanowi art. 101 ust. 7 u.p.s.: „Gmina właściwa ze względu na miejsce zamieszkania albo na ostatnie miejsce zameldowania na pobyt stały jest obowiązana do zwrotu wydatków gminie, która przyznała świadczenia w miejscu pobytu". W tym miejscu należy podkreślić, że jeżeli gmina właściwa uchyla się od spełnienia tego obowiązku, to gmina, która świadczenia udzieliła, ma prawo wystąpić o zwrot poniesionych wydatków do sądu powszechnego ${ }^{49}$. Spory o właściwość w analizowanych sprawach wynikają także z nieumiejętności ustalenia faktu, czy aktualna sytuacja życiowa danej osoby pozwala uznać ją za bezdomną w świetle art. 6 pkt 8 u.p.s..$^{50}$, a od tego zależy prawidłowe ustalenie właściwości miejscowej gminy. Tego rodzaju spory powodują wydłużenie czasu oczekiwania osoby bezdomnej na przyznanie świadczenia. Powodują także niepewność co do tego, który miejscowo organ administracji publicznej jest właściwy do wydania rozstrzygnięcia w przedmiocie udzielenia świadczenia.

\section{WNIOSKI}

Z przedstawionych rozważań wynika, że określanie sposobu ustalania właściwości miejscowej gminy w sprawach przyznawania świadczeń dla osób bezdomnych zajmuje ważne miejsce w pomocy społecznej. Ustalanie właściwości miejscowej gminy łączy się z istotnymi kwestiami natury prawnej z punktu widzenia bezdomnych oraz gmin zobowiązanych do udzielania im pomocy. Znajdują się wśród nich respektowanie woli osoby bezdomnej co do miejsca jej przebywania, efektywność świadczonej pomocy, a także bezwzględny obowiązek zwrotu wydatków poniesionych na udzieloną bezdomnemu pomoc. W sytuacjach, w których bezdomni wskazują na swoje emocjonalne przywiązanie do gminy, w której fak-

${ }^{48}$ M. Wierzbowski, A. Wiktorowska, Podmioty orzekajace, [w:] Postępowanie administracyjne - ogólne, podatkowe, egzekucyjne i przed sądami administracyjnymi, red. M. Wierzbowski, Warszawa 2017, s. 43-44.

49 S. Nitecki, op. cit., s. 705.

50 Postanowienie NSA z dnia 20 sierpnia 2017 roku, I OW 90/17, CBOSA. 
tycznie przebywają oraz na chęć uzyskania pomocy w tej właśnie gminie, udzielenie im pomocy przez gminę ich ostatniego miejsca zameldowania może być nieefektywne, jeśli z punktu widzenia gminy właściwej do rozpoznania wniosku o pomoc nie jest możliwe finansowanie pobytu bezdomnego w schronisku na terenie innej gminy, ponieważ na przykład występuje istotna różnica w odpłatności za pobyt w nim w porównaniu z odpłatnością obowiązującą w schronisku zlokalizowanym w gminie ostatniego miejsca zameldowania bezdomnego ${ }^{51}$. Biorąc zatem pod uwagę omówioną w artykule problematykę, należy uznać, że tworzenie prawa w dziedzinie pomocy społecznej nie powinno być nigdy celem samym w sobie. Pomoc społeczna ma służyć osobom znajdującym się w trudnych sytuacjach życiowych, z których szczególnie dramatyczną sytuacją jest bezdomność. Potrzeba realizacji postulatu racjonalnego tworzenia prawa w pomocy społecznej jest więc bardzo ważna, a ponadto należy ją odnosić do całości regulacji prawnej pomocy społecznej. Warto zatem podkreślić słuszność postulatów wyrażających konieczność zmiany istniejącego stanu prawnego w zakresie ustalania właściwości miejscowej gminy w sprawach przyznawania osobom bezdomnym świadczenia z u.p.s., jakim jest schronienie w schronisku dla bezdomnych.

\author{
THE THEORY OF RATIONAL LEGISLATOR \\ AND SOCIAL ASSISTANCE LAW. REMARKS ON THE WAY \\ OF DETERMINATION OF COMMUNE'S TERRITORIAL \\ JURISDICTION IN CASES REGARDING GRANTING \\ SOCIAL BENEFITS TO THE HOMELESS
}

\begin{abstract}
Summary
The article's aim is to analyse the legal regulation of article 101 of the Social Assistance Act of 12th March 2004. The mentioned article sets out the rules of the commune's territorial jurisdiction determination in cases regarding homeless people from the point of view of the theory of rational legislator. The interest presented in this issue in the literature, in practice, by the Polish Ombudsman, and the fact that it is a subject of many decisions of administrative courts shows its importance. The mentioned article of the Social Assistance Act creates a legal fiction whose aim is to ensure that every homeless person shall have access to social assistance benefits. However, it causes many problems in its implementation during the course of administrative procedures. They result in many jurisdiction conflicts between communes. This legal rule of determination of communes' territorial jurisdiction in cases regarding the homeless has an impact on the legal situation of homeless people, who apply for a given benefit from the social assistance system to the commune where they currently reside while in fact, they have the place of their last registered residence in a different commune. Legal and empirical methodologies of research were applied in the article.
\end{abstract}

Keywords: rationality, social assistance, homeless person, commune, territorial jurisdiction, conflicts of jurisdiction

51 Ibidem.

Przegląd Prawa i Administracji CXX, 2020, cz. 1 i 2

(C) for this edition by CNS 


\section{BIBLIOGRAFIA}

Adamiak B., [w:] Kodeks postępowania administracyjnego. Komentarz, red. B. Adamiak, J. Borkowski, Warszawa 2014.

Adamiak B., Funkcje prawa o postepowaniu administracyjnym i prawa o postępowaniu sadowoadministracyjnym, [w:] Postępowanie administracyjne i sadowoadministracyjne, red. B. Adamiak, J. Borkowski, Warszawa 2009.

Cendrowicz D., Przestrzeń pewności prawnej jednostki w materialnym i procesowym prawie administracyjnym, [w:] Przestrzeń w prawie administracyjnym, red. J. Zimmermann, Warszawa 2013.

Cendrowicz D., Sytuacja administracyjnoprawna adresata świadczeń z zakresu pomocy społecznej, Warszawa 2017.

Chauvin T., Stawecki T., Winczorek P., Wstep do prawoznawstwa, Warszawa 2017.

Czaja J., O nieracjonalności pojęcia „racjonalnego ustawodawcy”, [w:] Studia z filozofii prawa, red. J. Stelmach, Kraków 2001.

Duniewska Z., Kasiński M., Jaworska-Dębska B., Stahl M., Michalska-Badziak R., Olejniczak-Szałowska E., Ku dobremu prawu. Z problematyki pojęcia i wymogów dobrego prawa, [w:] Racjonalny ustawodawca. Racjonalna administracja. Pamięci prof. Eugeniusza Smoktunowicza, red. D.R. Kijowski, A. Miruć, A. Budnik, Białystok 2016.

Jóźwik S., Klimowicz I., O postępowaniu z bezdomnymi. Cz. II, „Doradca w pomocy społecznej” 49 (listopad 2017), https://doradcawpomocyspolecznej.pl/artykul/o-postepowaniu-z-bezdomnymi-cz-ii (dostęp: 23.12.2019).

Kuta T., Sytuacja człowieka we wspótczesnej administracji, „Prawo” 2, Wrocław 1972.

Lipowicz I., Kilka uwag w kwestii racjonalności w prawie administracyjnym, [w:] Racjonalny ustawodawca. Racjonalna administracja. Pamięci Profesora Eugeniusza Smoktunowicza, red. D.J. Kijowski, A. Miruć, A. Budnik, Białystok 2016.

Matczak M., Summa iniuria. O błędzie formalizmu w stosowaniu prawa, Warszawa 2007.

Nitecki S., Komentarz do ustawy o pomocy społecznej wraz z przepisami wykonawczymi, Wrocław 2013.

Nowak L., Interpretacja prawnicza. Studium z metodologii prawoznawstwa, Warszawa 1973.

Pomyst ekspertów RPO: pomoc dla osoby bezdomnej - w catym kraju, a nie tam, gdzie była ostatnio zameldowana, https://www.rpo.gov.pl/pl/content/rpo-trzeba-zmienic-zasady-pomagania-osobom-w-kryzysie-bezdomnosci (dostęp: 21.12.2019).

Sierpowska I., Pomoc społeczna jako administracja świadczaca, Warszawa 2012.

Truskolaska E.M., Kryminologiczne aspekty bezdomności, rozprawa doktorska, Białystok 2018, https://repozytorium.uwb.edu.pl/jspui/bitstream/11320/7113/1/EM_Truskolaska_Kryminologiczne_aspekty_bezdomnosci.pdf (dostęp: 22.12.2019).

Wierzbowski M., Wiktorowska A., Podmioty orzekajace, [w:] Postępowanie administracyjne ogólne, podatkowe, egzekucyjne i przed sadami administracyjnymi, red. M. Wierzbowski, Warszawa 2017.

Wronkowska S., Podstawowe pojęcia prawa i prawoznawstwa, Poznań 2003.

Wronkowska S., Prawodawca formalny jako wzór dla prawodawcy faktycznego, [w:] Szkice z teorii prawa i szczególowych nauk prawnych, red. S. Wronkowska, M. Zieliński, Poznań 1990.

Wróblewski J., Teoria racjonalnego tworzenia prawa, Wrocław 1985.

Wystąpienie RPO do Ministerstwa Rodziny z dnia 11 października 2018 roku w sprawie problemów osób w kryzysie bezdomności, III.7065.193.2018.JJ, https://www.rpo.gov.pl/sites/default/files/Wystapienie_RPO_do_Ministerstwa_Rodziny_ws_problemow_osob_w_kryzysie_bezdomnosci.pdf (dostęp: 23.12.2019).

Zimmermann J., Aksjomaty prawa administracyjnego, Warszawa 2012. 